\title{
Monetary Policy and Stock Returns: Are Stock Markets Efficient?
}

\author{
LAWRENCE S. DAVIDSON and RICHARD T. FROYEN
}

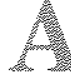
all relevant information. For example, if monetary policy affects stock returns, then an efficient stock market rapidly digests and incorporates all news about monetary policy. Consequently, past policy actions will have little value or explanatory power in understanding current stock returns. Previous tests of stock market efficiency have examined the relationship between the timing of the growth of money and stock returns. Although several early studies found that stock returns lagged behind money growth - evidence of stock market inefficiency the results of recent studies have supported the efficient market hypothesis. ${ }^{1}$
\end{abstract}

The purpose of this article is to provide further evidence on the timing of the relationship between monetary policy changes and stock retums by estimating models that express stock retums as functions of anticipated and unanticipated monetary policy measures. These models extend previous work in several directions. First, past studies gen-

Lawrence S. Davidson, an associate professor of business econonics and public policy at Indiana University, is a visiting scholar at the Federal Reserve Bank of St. Louis. Richard $\Gamma$ Froyen is an associate professor of economics at the University of North Carolina.

${ }^{1}$ Examples of studies that indicated a lag in the adjustment of stock retums to changes in money growth zates are: Michael $\mathrm{J}$. Hamburger and Lev is A. Kochin, "Money tnd Stock Prices: "The' Channels of minfuence," Joumal of Finance (December 1971), pp. 1045-66; Michael W. Keran, "Expectations, Money, and the Stock Market," this Rethe (January 1971), pp. 164-31; and Beryl W. Sprinkel, Money and Stock Prices (Richard D. Trwin, Inc., 1964). Recent studies that support the market effociency postulate inchude: Michael S. Rozeff, "Money and Stock Prices: Market Efficiency and the Lag in Effect of Monetary Policy," Joumal of Financial Exomomics (September 1974), pp. 245-302; John Kraft and Arthur Kraft, "Determinants of Common Stock erally have divided money growth into anticipated and unanticipated components in a mechanical or ad hoc fashion. ${ }^{2}$ We compare these results with estimates of anticipated money growth measured by the fitted values of previously estimated monetary policy reaction functions. This enables us to determine whether the efficient market findings are robust across differing aggregates and decompositions of monetary policy into anticipated and unanticipated components.

Second, previous studies focused on the relationship between money growth rates and stock retums. But, during much of the period covered by these studies, the Federal Reserve's short-run (month-tomonth) operating target was the federal funds rate. Therefore, in addition to estimating relationships between stock returns and money growth rates, we estimate models relating stock returns and both anticipated and unanticipated monetary policy actions using the federal funds rate. Again, anticipated and unanticipated policy actions will be de-

Prices: A Time Series Analysis," Joumal of Finance (May 1977), pp. 417-25, and "Common Stack Prices: Some Observations," Southem Econonic Joumal (Jantary 1977), pp. 1365-67; R. V. L. Cooper, "Efficient Capital Markets and the Quantity Theory of Money,"Jou mal of Finance (Jume 1974), pp. 887-908; Richard J. Rogalski and Joseph D. Vinso, "Stock Returns, Money Supply and the Direction of Causality, "Joumal of Finance (Septenber 1977), pp. 1017-30; James B. Kehr and David Leonard, "Monetaty Aggregates, the Stock Market and the Direction of Causality," loumal of the Midleest Finance Association (1980), pp. 47-57; and J. Emest Tanmer and John M. Trapani "Can the Quantity Theory be Used to Predict Stock Prices - Or Is the Stock Market Efficient?" Southem Exonome Joumal (Octobet 1977), pp. 261-70.

"Rozeff, "Money and Stock Prices," for exmple, assumes that anticipated money growth in a given month depends on money growth in the past three months. 
rived from an empirical reaction function in which the federal funds rate is the dependent variable.

Third, we extend the time period in earlier studies through 1977. This allows us to examine the monetary policy/stock refum relationship in both a period of low stable inflation (1954-65) and one of higher and more variable inflation and money growth (196677).

Finally, for the period from 1974 through 1976 , we estimate models that relate weekly stock returns to the anticipated and unanticipated components of weekly money growth. Most previous work on this topic used quarterly or monthly data. ${ }^{3}$ Estimates with weekly data provide a finer test of the efficient market hypothesis.

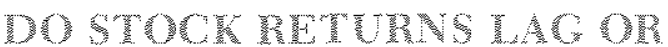 I}

Several recent studies of the relationship between money growth rates and stock returns have found that future money growth rates affect current stock returns. Thus, stock retums appear to lead money growth rates. ${ }^{4}$ Other studies, however, do not find such effects. ${ }^{5}$

The finding that stock prices lead money growth has been interpreted in several different ways. One interpretation is that stock prices are a causal influence on money growth. However, as Rozeff points out, within the general equilibrium setting of financial markets, it is arbitrary to single out stock returns as a causal variable. ${ }^{6}$ Rather, the evidence that future money growth rates affect current returns may be a reflection of the influence of other variables on both stock prices and money growth, with stock prices adjusting more quickly and, therefore, leading money growth rates.

Another interesting interpretation of this finding is provided by the "reversed causation with accurate anticipations" model. ${ }^{7}$ In this model, causation runs

${ }^{3}$ One recent exception is Neil G. Berkman, "On the Significance of Weekly Changes in MI," New England Economic Reviet (May/June 1978), pp. 5-22.

4See, for example, Rozeff, "Money and Stock Prices;" Kraft and Kraft, "Determinants of Common Stock Prices," and Rogalski and Vinso, "Stock Retums, Money Supply and the Direction of Causklity."

sSee, for example, Kehr and Leonard, "Monetary Aggregates, the Stock Market and the Direction of Calsality."

see Rozeff, "Money and Stock Prices."

${ }^{7}$ See Rozeff, "Money and Stock Prices," pp. 275-76. from currently anticipated money growth to stock returns. The apparent effect of future money growth reflects the accurate anticipations of future money grow th by the market. It is these accurate predictions of future money growth that affect current stock returns.

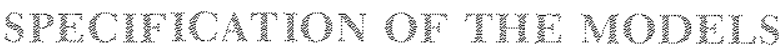

This section describes two simple models of equity return determination. Tobin's theoretical model of the financial sector stressed the importance of the return on capital as the link between the real and financial sectors. ${ }^{8}$ His model established a potential causal connection between the exogenous variables of the commodities and financial markets and the return on equities (ownership claims on the capital stock). The first of the two models presented here is a simple version of Tobin's, originally estimated by Rozeff. 9 This model stressed the linkage between monetary aggregates and the equity return. It imposed the additional restriction that only unanticipated changes in the growth rate of money $\left(\mathrm{g}^{\mathrm{a}}\right)$ cause unanticipated movements in the equity return $\left(\mathrm{R}^{\mathrm{u}}\right)$.

Rozeff's "predictive monetary portfolio" model relates the unanticipated current return on equities $\left(R_{t}^{u}\right)$ to past unanticipated changes in monetary growth rates, that is,

(1) $\mathbf{R}_{t}^{\mathrm{a}}=f\left(\mathrm{~g}_{\mathrm{t}-1}^{\mathrm{u}}, \ldots, \mathrm{g}_{\mathrm{t}-\mathrm{a}}^{\mathrm{u}}\right)+\epsilon_{\mathrm{t}}$,

where $R_{t}^{u}$ is the unanticipated movement in the equity return, defined as the actual return $\left(R_{t}\right)$ minus the expected return conditioned on all available past information $\left(E\left[R_{t} / B_{t-1}\right]\right)$. Unanticipated money growth in period $t-i, g_{t-i}^{1}$, is measured as the change in the money growth rate between $t-i$ and $t-i-1$. The error term, $\epsilon_{t}$, is assumed to be a normally distributed random variable with a mean of zero and a constant, finite variance. Rozeff assumed that the expected value of the nominal equity return is constant $\left(E\left[R_{t} / B_{t-1}\right]=C_{0}\right)$ and the monthly empirical counterpart of the predictive model is:

(2) $R_{t}=C_{0}+\sum_{i=1}^{16} a_{i} g_{t-1}^{n}+\epsilon_{2 t}$.

where $C_{0}$ and $a_{i}$ are parameters to be estimated.

\footnotetext{
8atanes Tobin, "A General Equilibrium Approach to Monetary Theory," Joumal of Money, Credit, and Banking (February 1969), pp. 15.29 .

'See Rozeff, "Money and Stock Prices," pp. 255-66.
} 
To evaluate the relative importance of the most recent monetary information, Rozeff also estimated the nonpredictive monetary portfolio model. In this model, the contemporaneous money surprise is added; the lag on the monetary surprises starts at zero instead of one:

(3) $R_{t}=C_{0}+\sum_{i=0}^{16} a_{i} g_{t-i}^{\mathrm{B}}+\epsilon_{3 t}$.

A final variant of this model assmmes that market participants form expectations of future changes in monetary growth. If these expectations are at least unbiased, then future monetary growth rates would cause changes in current equity returns. Rozeff's empirical nonpredictive monetary portfolio model with anticipations adds eight leads (negative lags) to equation $3: 10$

$$
\text { (4) } R_{t}=C_{0}+\sum_{i=-8}^{16} a_{i} g_{t i}^{u}=\epsilon_{4 t} \text {. }
$$

To test whether past information about unexpected monetary growth influences current stock returns, we examine the statistical significance of the lagged unanticipated money growth terms in the predictive model (equation 2). If the stock market is efficient, the coefficients on the lagged terms should be equal to zero $\left(a_{i}=0, i=1, \ldots, n\right)$. An $F$-test is used to test this hypothesis; an F-value significantly greater than 1.0 would suggest that the stock market was inefficient, since past information would affect current stock returns.

On the other hand, a significant F-value for a similar test of the coefficients in the nonpredictive models (equations 3 or 4 ) does not indicate market inefficiency. The finding that only current monetary growth affects returns smply establishes the importance of monetary variables in equity return determination. If future, but not past, money growth affects current returns, this suggests a forwardlooking propensity of the market which also is not inconsistent with an efficient market.

The second model of equity returns considered here is referred to as the Farna approach." In this

\footnotetext{
${ }^{10}$ Future values of unanticipated money grow th should not cause cument stock market retums to change. However, the exact intempretation of $\mathrm{g}_{1}^{31}$ is not unambiguous. It could be reinterpreted as the perfectly correct anticipated future change in money growth. In that case, it would be an indicat or of the forward looking propen sify of the maket.

${ }^{11}$ This approach is set ot in Engene F. Fama, "Short-Tem Interest Rates as Predictors of Inflation," American Economic Reviete (Jnne 1975), pp. $269-82$.
}

model, the nominal retum on stocks $\left(R_{t}\right)$ is assumed to be composed of the real return $\left(r_{t}\right)$ and a premium for expected inflation $\left(\pi_{t}\right)$ - a Fisher effect for stock returns:

(5) $\mathrm{R}_{4}=\mathrm{r}_{\mathrm{t}}+\pi_{i}$.

From equation 5, we can write the expected value of the nominal return conditioned on information available from period $t-1\left(B_{t-1}\right)$, as

(6) $\mathrm{E}\left(\mathrm{R}_{\mathrm{t}} / \mathrm{B}_{\mathrm{t}-\mathrm{1}}\right)=\mathrm{E}\left(\mathrm{r}_{\mathrm{l}} / \mathrm{B}_{\mathrm{t-1}}\right)+\mathrm{E}\left(\pi_{\mathrm{t}} / \mathrm{B}_{\mathrm{t}-1}\right)$.

If we assume a constant real mean of stock returns $\left(c_{0}\right)$, we can rewrite equation 6 as

(7) $\mathrm{E}\left(\mathrm{R}_{\mathrm{t}} / \mathrm{B}_{\mathrm{t}-1}\right)=c_{0}+\mathrm{E}\left(\pi / \mathrm{B}_{t-1}\right)$

Since $E\left(R_{t} / B_{t-1}\right)$ is equal to the actual nominal return on stocks $\left(\boldsymbol{R}_{t}\right)$ minus its unanticipated component $\left(\mathrm{R}_{t}^{\mathrm{i}}\right)$, we can transform equation 7 into an expression for the actual nominal stock return:

(8) $R_{t}=c_{0}+R_{t}^{\prime \prime}+\mathrm{E}\left(\pi_{t} / B_{t-1}\right)$.

Equation 8 then can be converted into a relationship between money growth and nominal stock returns if we express (as in equation 1) the unanticipated component of stock retums as a function of unanticipated changes in money growth and if, further, we express the expected inflation rate as a function of expected money growth. With these assumptions, our expression for nominal stock returns becomes

$$
\begin{aligned}
& \text { (9) } R_{t}=c_{0}+f\left(g_{t}^{a 1}, g_{1-1}^{a}, \ldots, g_{t-11}^{u}\right) \\
& +h\left(g_{t}^{*}, g_{t-1}^{*}, \ldots, g_{t}^{*} \cdot m_{2}\right)+v_{t},
\end{aligned}
$$

where $\mathrm{g}_{t}^{*}$ is the expected rate of growth of the money stock, and $\mathrm{h}$ is the function relating expected money growth to expected inflation. The empirical counterpart to equation 9 used in our estimation is

(10) $R_{t}=c_{0}+\sum_{i=0}^{n_{k}} b_{i} g_{t-j}^{t h}+\sum_{j=0}^{n_{2}} d_{j} g_{k-j}^{*}+v_{t}$,

where various lag lengths and several different measures of anticipated and unanticipated money growth are employed.

Additionally, one test uses the federal funds rate rather than a monetary aggregate as the monetary policy variable. The effects of this substitution on the theoretical interpretation of our models of equity return are discussed below.

Using the Fama (or Fisher) model of stock returns, we can also test for market efficiency. Market efficiency implies that lagged unanticipated changes in 
money growth rates would not affect current stock retums ( $b_{i}=0$ for $i>0$ in equation 10 ). In the Fama approach, however, lagged anticipated changes in money growth rates might affect current stock returns through an effect on expected future inflation. This result would not violate market efficiency; it would simply be an element of $\mathrm{E}\left(\mathrm{R}_{t} / \mathrm{B}_{\mathrm{t}-1}\right)$ and would not provide a basis for any profitable tradingrules. ${ }^{22}$ This effect of anticipated monetary policy on stock returns is another channel by which monetary policy may affect stock prices - even in an efficient market - an effect we test for in the following section.

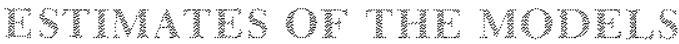

Five sets of model estimates are presented. In all five, the measure of the nominal equity retum is the percentage change (measured from the last business day in each month or week) in the overall index of all stock prices on the New York Stock Exchange.13 These tests employ a variety of monetary policy measures. ${ }^{\mathbf{t}}$ These include: 1 ) percentage changes in actual, anticipated and unanticipated $M I$ and the monetary base, and 2) anticipated and unanticipated values of the federal funds rate.

The policy measures in all the tests, except those with weekly data, are changes in average monthly values. Retums are changes between the last business day of each month. This specification relates the cumulative stock price change from the end of one month to the next to the average month-to-month change in the monetary policy variable. As a result, the stock retum variable is more sensitive than the

\footnotetext{
12 See Rozeft, "Money and Stok Prices," p. 260.

${ }^{13}$ An altemative measure includes dividends, but because its variance is so dominated by stock price clatuges, it performs almost identically to the index which contains only prices. This altemative measure is not used in our tests.

${ }^{14}$ The se measures of monetary policy each have limatations for the testing of the efficient market hypothesis. Tests of this hypothesis nust distinguish between information which is currently known and used by maket participants and that which is not. In fact, we do not know what in formation was avallable to and used by these agents. In this research, we have limited the monetary policy measures to those listed above. We have not tried nat rower or broader measures of money like nonborrowed reserves or M2, nor have we used seatsonaly unadiusted versions of Ml or the monetary base. Our test have selectively employed both revised and initially announced seasonally adjusted versions of Ml. Since seasonally adjusted data are revised several times, it would seem preferable to use the initially announced numbers since those were the ones avaliable to market particinants. Furthemore, Coutenay C. Stone and Jeffrey B. C. Olson, "Are the Preliminary Week-to-Week Fluctuations in Ml Biased?" this Review (December 1978), pp. 13-20, have shown with
}

policy variables to last-day-of-the-month activity. Changes in the average monthly value would appear to be the proper measure of the shift in monetary policy from month to month. We relate this to the cumulative change in stock prices for the month. This does mean, however, that while the dependent and independent variables pertain to the same time period, they weight daily observations within the time period differently. Our tests with weekly data therefore provide more in tra-month precision.

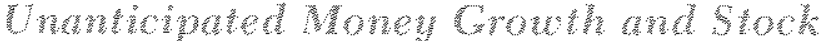

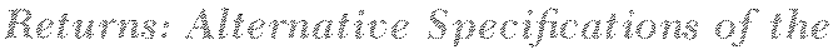 Base Whaters}

The models in equations $2-4$ specify that unanticipated money growth affects the unanticipated stock return. Rozeff's tests make the following two explicit assumptions:

i) $R_{q}^{u}=R_{t}-C_{0}$, and

ii) $g_{t}^{n 1}=g_{t}-g_{t-1}$.

The unanticipated return is a deviation from a mean $\left(R_{f}-C_{0}\right)$, while the unanticipated money growth rate is a first difference $\left(g_{t}-g_{t-1}\right)$. This section compares the results based on these assumptions with two alternative specifications. The first of these we call the differenced model:

iii) $R_{\xi}^{u}=R_{t}-R_{i-1}$,

iv) $\mathrm{g}_{t}^{41}=\mathrm{g}_{\mathrm{t}}-\mathrm{g}_{\mathrm{t}-1}$.

The second is called the mean deviation model:

weohly data that the revised seasonally adjusted series is largely independent of the unrevised series and therefore is a poor proxy for that data, Our weekly aggregate tests, therefore, employ the unrevised growth rates of seasonally adjusted Ml.

This use of initially amounced data is not without drawbacks. For example, since initial anouncements have been shown to be urreliable indicators of how money is performing, market participants may either ignore seasonally adjusted data or they may modify it. One useful modification would discount the announcement with what agents think is the true seasonal adjustment. If they do this correctly, then they are using what tums out to be the actual revisions. If they use seasonal adjustment factors that are different from the true ones, they are using an unobservable series. Our monthly aggregate tests use the revised, seasonally adjusted growth rates of $\mathrm{MI}$.

The monetary reation function tests do not rely totally upon either revised or un revised data. For example, the consumer price index and the unemployment rate, which are used to predict the monetary base, ane not regularly revised. However. the monetary base itself, like $M 1$, is revised fremuently. Finally, the tests with the lederal funds rate have no data revision problems since this series is not revised. 
Table 1

Summary Statistics for Lead-Lag Money Growth (g) and Equity Return (R) Models'

\begin{tabular}{|c|c|c|c|c|c|c|c|c|c|c|c|}
\hline \multirow[b]{3}{*}{ Model } & \multirow{3}{*}{$\begin{array}{l}\text { lag }(\mathrm{lad}) \\
\text { spot }\end{array}$} & \multicolumn{5}{|c|}{$1954 \quad 1965$} & \multicolumn{5}{|c|}{$1966 \_1977$} \\
\hline & & \multirow[b]{2}{*}{$E$} & \multirow[b]{2}{*}{$\bar{R}^{2}$} & \multirow[b]{2}{*}{ DW } & \multicolumn{2}{|c|}{$\begin{array}{l}\text { Number of } \\
\text { sgmilican } \\
\text { coeflicients }\end{array}$} & \multirow[b]{2}{*}{$f$} & \multirow[b]{2}{*}{$\mathrm{R}^{2}$} & \multirow[b]{2}{*}{ ow } & \multicolumn{2}{|c|}{$\begin{array}{l}\text { vumber of } \\
s \mathrm{gm} \text { lcant } \\
\text { coefflcients }\end{array}$} \\
\hline & & & & & Lags & Leads & & & & Lags & Leads \\
\hline \multicolumn{12}{|l|}{ Mxed } \\
\hline 2 & 16101 & 1382 & 149 & 178 & 2 & 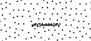 & 889 & 100 & 180 & 0 & 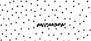 \\
\hline 3 & 16100 & 1296 & 150 & 129 & 1 & 0 & 859 & 103 & 183 & 0 & 0 \\
\hline 4 & $1610(9)$ & 1488 & 250 & 192 & 1 & 2 & 2790 & 381 & 187 & 3 & 5 \\
\hline \multicolumn{12}{|c|}{ Dlferenced } \\
\hline 182 & 16101 & 1849 & 178 & 283 & 0 & 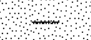 & 1480 & 147 & 290 & 0 & $\rightarrow$ \\
\hline 3 & 16100 & $1888^{\circ}$ & 192 & 283 & 0 & 0 & 1720 & 177 & 288 & 0 & 1 \\
\hline 4 & $1610(9)$ & 1285 & 214 & 2,85 & 0 & 0 & $2990^{\prime}$ & 386 & 284 & 0 & 2 \\
\hline \multicolumn{12}{|c|}{ Mean Deviation } \\
\hline 82 & 16101 & 1748 & 170 & 180 & 4 & 3 & 1150 & 119 & 185 & 0 & 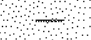 \\
\hline 3 & 16101 & 1649 & 172 & 182 & 4 & 0 & 1070 & 119 & 186 & 0 & 0 \\
\hline 4 & $1610(9)$ & 1720 & 267 & 195 & 1 & 1 & 29408 & 384 & 191 & 2 & 3 \\
\hline
\end{tabular}

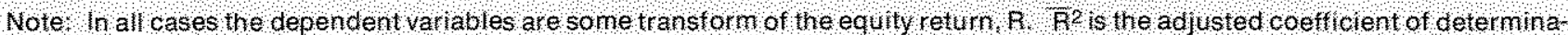
tion $F$ is the $F$-value, and D W is the Durbin -Watson statistic A ( 7 ) implies rejection of the null hypothesis at the $95 \%$ (99\%) level The null hypothesis states that the estimated coeficents of the ndependent varlables edual zero. The leads columns include the contemporaneous terms.

toata are monthly observations.

v) $R_{f}^{\prime \prime}=R_{t}-C_{0}$,

vi) $g_{t}^{n t}=g_{t}-g_{0}$

where $\mathrm{C}_{0}$ and $\mathrm{g}_{0}$ are the sample-period means of $\mathrm{R}$ and $g$, respectively.

Since the original Rozeff specification mixes deviations from means $\left(\mathbb{R}_{t}-\mathrm{C}_{0}\right)$ with first differences $\left(g_{t}-g_{t-1}\right)$, we refer to this as the mixed model. None of the three versions inherently makes more sense than the others. Our intent here is to see how sensitive the original specification is to these minor changes.

Table 1 provides estimates of the original empirical specifications of the three models: the mixed model, ziven by equations 2,3 and 4 , and the modified specifications which we term the differenced model and the mean deviation model. The estimates in the table cover two subperiods, $1954-65$ and $1966-$ 77.

The results in table 1 offer no clear rejection of Rozeffs specification. All three models explain more of the variance of equity retums when current or future money grow th is included in the regressions. In the 1966-77 time period, individual coefficients on past monetary information are never significant, nor are they ever significant as a group. In this period, the effect of future money is highly significant, tripling the explanatory power of the estimated models.

In the earlier period, there are no unambigtous differences among the models. The $\overline{\mathrm{R}}^{2}$ reveals rela* tively equal explanatory power. The differenced model show a statistically significant effect of the 16 lags of money growth, yet no single coefficient is statistically significant. This model exhibits a high degree of atocorrelation; therefore, the F-tests should be interpreted with caution. ${ }^{15}$ The mean deviation model also shows an apparent significant effect of past money growth in the early period. However, when future terms are added to the equation, the number of lagged significant coefficients falls to only one. As a whole, these results offer no clear rejection of stock market efficiency. The effects of future money growth on stock returns are also robust with respect to the type of specification changes we have made.

\footnotetext{
1.5 As is well known, antocorrelation leads to a bias in the standarl ermor of the regression. With negative antocomelation, the direction of the bias could be pesitive or negative.
} 
Table 2 Reaction Function Estimates of Unanticipated Monetary
Policy $\left(\tilde{\mathbf{g}}_{1}^{u}, \tilde{\mathbf{g}}_{2}^{U}\right)$ and Equity Returns $(1954: 7$ to 1972:3)

\begin{tabular}{|c|c|c|c|c|c|c|c|}
\hline \multirow{2}{*}{$\begin{array}{l}\text { rodependent } \\
\text { vartable }\end{array}$} & \multirow[b]{2}{*}{ ModeI } & \multirow{2}{*}{$\begin{array}{l}\text { Lag }(\mathrm{ead}) \\
\text { spectiflcation }\end{array}$} & \multirow[b]{2}{*}{$F$} & \multirow[b]{2}{*}{$\mathrm{n}^{2}$} & \multirow[b]{2}{*}{ DW } & \multicolumn{2}{|c|}{$\begin{array}{l}\text { Number ot } \\
\text { significant } \\
\text { coefficients }\end{array}$} \\
\hline & & & & & & Lags & Leads \\
\hline 9 & 3 & $\begin{array}{l}16 \text { to } \\
16 \text { to } 0 \\
16 \text { to }(9)\end{array}$ & $\begin{array}{r}655 \\
621 \\
946\end{array}$ & $\begin{array}{r}051 \\
051 \\
117\end{array}$ & $\begin{array}{l}178 \\
178\end{array}$ & 0 & 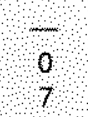 \\
\hline 9 & $\frac{2}{3}$ & $\begin{array}{ll}16 & 10 \\
16 & 0 \\
16 & 0\end{array}$ & $\begin{array}{l}896 \\
969 \\
2660^{\circ}\end{array}$ & 068 & $\begin{array}{l}179 \\
185\end{array}$ & $\begin{array}{l}0 \\
0 \\
0\end{array}$ & 0 \\
\hline
\end{tabular}

Isee note, table 1 Data are nonthly observations.

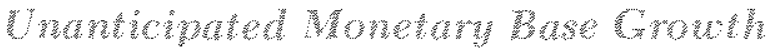

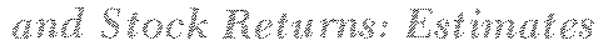

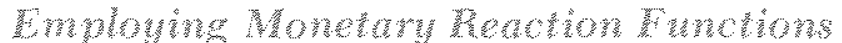

The basic mixed model is retained in this section, but two different proxies for unanticipated monetary policy actions $\left(\mathrm{g}^{\mathrm{u}}\right)$ are tried. In these tests, we assume that agents are rational and act as if they know the appropriate function guiding monetary policy.

Table 2 presents the results of estimating equaw tions 2,3 and 4 using two different proxies for unanticipated money growth. The first of these, denoted $\hat{\mathrm{g}}_{1}^{\mathrm{u}}$, comes from Froyen's monetary policy reaction function for the monetary base. ${ }^{16}$ This function, which we assume is used to forecast future growth rates of the monetary base, relates the latter to past values of the Federal Reserve's assumed goal variables: the unemployment rate, inflation rate, balance of payments and the outstanding government debt held by the public. The estimated function is used to predict the level of the monetary base.

If $\mathrm{M}_{\mathrm{t}}^{*}$ is the prediction of the monetary base based on the estimated reaction function, then we can define the anticipated monetary base growth rate as ${ }^{17}$

$\tilde{\mathrm{g}}_{\mathrm{l} . \mathrm{t}}^{*}=\left(\mathrm{M}_{\mathrm{t}}^{*}-\mathrm{M}_{\mathrm{t}-1}^{*}\right) / \mathrm{M}_{\mathrm{t-1}-\mathrm{l}}^{*}$

I See Richard T. Froyen, "A Test of the Endogeneity of Monetary

Policy," Journal of Econometrics (July 1974), pp. 175-88.

${ }^{17}$ Alternatively, we tried a variant of this form where

$$
\mathrm{g}_{3, \mathrm{t}}^{*}=\left(\mathbf{M}_{\mathrm{t}}^{*}-\mathbf{M}_{\mathrm{t}-\mathrm{l}}\right) / \mathbf{M}_{\mathrm{t}, \mathrm{l}} \text {. }
$$

The results were not different enough to warrant further discussion.
Therefore, a first proxy for unanticipated monetary base growth is

$\vec{g}_{1, t}^{\xi}=\tilde{g}_{1, t}^{*}-g_{t}$

The second proxy for unanticipated growth $\left(\tilde{\mathrm{g}}_{2, \mathrm{t}}^{\mathrm{u}}\right)$ is based on a simple third-order autoregressive process similar to the specification used by Rozeff:

$\tilde{g}_{2, t}^{\mathrm{g}}=\tilde{g}_{2, \mathrm{t}}^{*}-\mathrm{g}_{\mathrm{t}}$,

where

$\tilde{\mathrm{g}}_{2, t}^{*}=\hat{\alpha}_{0}+\hat{\alpha}_{1} \mathrm{~g}_{\mathrm{t}-1}+\hat{\alpha}_{2} \mathrm{~g}_{\mathrm{t}-2}+\hat{\alpha}_{3} \mathrm{~g}_{\mathrm{t}-3}$.

The results in table 2 again support the efficient market hypothesis. There is no clear evidence that past unanticipated monetary base growth significantly affects current stock returns using any of the proxies tested here. While there are numerous significant lag coefficients in the git equation, they are not significant until leads are added, and even then the $F$-value is not significant. With regard to the effects of future monetary base growth on current stock retums, the pattern of the results in table 2 is in teresting. When anticipated monetary base growth is measured by the simple autoregressive specification, and future "unanticipated" monetary base growth is taken to be money growth that cannot be predicted with that specification, $\tilde{g}_{2, t}^{\mathrm{u}}$, our results show a significant effect for these future tems. However, for the proxy constructed on the basis of the estimated monetary policy reaction function, $\tilde{g}_{1, t}$, future unanticipated monetary base growth has no significant effect on current stock returns. 
Table 3

Anticipated vs. Unanticipated Monetary Base Growth and Equity Returns $(1954: 7$ to 1972:3)

\begin{tabular}{|c|c|c|c|c|c|c|c|}
\hline \multirow{2}{*}{ Antcipared } & \multicolumn{2}{|c|}{ specification } & \multirow[b]{2}{*}{$\mathrm{p}$} & \multirow[b]{2}{*}{$n^{2}$} & \multirow[b]{2}{*}{ ow } & \multicolumn{2}{|c|}{$\begin{array}{l}\text { Number of } \\
\text { significant } \\
\text { coefficients }\end{array}$} \\
\hline & 90 & $0^{6}$ & & & & $9^{4}$ & 9 \\
\hline 92 & 16 & в & 969 & 078 & 183 & 1 & 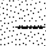 \\
\hline 91 & 16 & 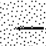 & 621 & 051 & 178 & 0 & 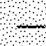 \\
\hline 9 & 16 & 0 & 1014 & 081 & 185 & 1 & 0 \\
\hline 9 & 16 & 0 & 4614 & 054 & 480 & 0 & 0 \\
\hline $9_{2}$ & 16 & 6 & 1001 & 113 & 183 & 0 & 0 \\
\hline 9 & 16 & 6 & 890 & 102 & 185 & 0 & 1 \\
\hline
\end{tabular}

TSee note table 1 Gata are nonhly observations

One interpretation of these results is that future "unanticipated" monetary policy actions based on the autoregressive proxy are not in fact unanticipated. Information other than past monetary base grow th information that is available to the public and, if the reaction function specification is correct, information that does affect future money growth - may enable the public to correctly anticipate such future monetary base growth. Since the prediction of the reaction function already incorporates such available information, the public cannot forecast future unanticipated monetary base growth as measured by reaction function residuals; therefore, these future residuals do not affect current stock retums. Our results then are consistent with Rozeff's "reversed causation with correct anticipations" model, where the apparent effect of future monetary base growth on stock returns reflects the public's correct forecasts of future monetary base growth on the basis of currently available information.

\section{Antripatod and Undwichat

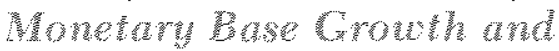

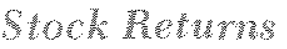

We discussed previously the Fama version of the model (equation 9), where both anticipated and unanticipated values of monetary policy should affect equity returns. In this section, we again use monetary policy reaction functions to differentiate anticipated and unanticipated policies. The model tested here is the empirical specification of the Fama model given by equation 10 .
These estimates are presented in table 3 . We use the same proxies for unanticipated money growth and, in this case, the corresponding measure of anticipated monetary base growth, as for the estimates in table 2 . The table is divided into three parts: The first two lines include only unanticipated monetary base growth. The second two add only the concurrent anticipation of monetary base growth. The third pair allows up to six months lagged values of anticipations of future monetary base growth. In each of these, unanticipated monetary policy has the current as well as 16 lagged values.

The results are not inconsistent with the efficient market hypothesis, since unanticipated monetary base growth, current or lagged, has no significant effect on stock returns. According to equation 9 , however, anticipated monetary base growth should have a positive effect on stock returns, if there is a constant expected real return and if anticipated monetary base growth affects money growth and, thereby, anticipated inflation. Our results do not show this effect and would seem to indicate that the expected real return on stocks is negatively affected by expected inflation that results from anticipated monetary base growth. This follows since the expected real return declines with anticipated inflation, unless there is an offsetting increase in the nominal return. ${ }^{18}$

\footnotetext{
¿Famat uses a general equilibrim approach and conchudes that real retums vary with expectations of future real economic activity. He also argues that apparent correlations between real stock retams and expected inflation or money growth rates are spurious. See Eugene F. Fama, "Stock Retums, Real Activity, Inflation, and Money," American Economic Review (September 1981), pp. 545-65.
} 


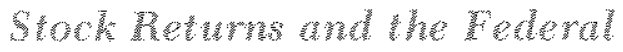

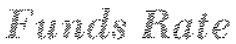

If the monetary authority pegs the federal funds rate, the money supply becomes endogenous, and changes in the setting of the rate may be taken as an exogenous variable. In practice, the federal funds rate may change for reasons other than policy, especially over short intervals. Consequently, these tests may reflect not only how efficiently the market absorbs information about monetary policy but also the impact of other information embodied in movements in the federal funds rate. Nevertheless, they are useful in ascertaining how ehanges in the federal funds rate are internalized by the market during a period when the expressed policy was to maintain that rate within a narrow range.

In the model with monetary aggregates, anticipated inflation was approximated by anticipated monetary growth. It is less appropriate to think of anticipated changes in the federal funds rate as a proxy for anticipated inflation. However, changes in the anticipated federal funds rate that signal changes expected in financial markets will still provide important information in efficient markets. The tests in this section remain, therefore, as tests of market efficiency. They do, however, have less explicit theoretical development that explains exactly how monetary policy affects stock returns.

To split movements in the federal funds rate into anticipated and unanticipated components, we use the monetary policy reaction function estimated by Abrams, Froyen and Waud in which the federal funds rate is the dependent variable. ${ }^{19}$ The fitted values from the estimated reaction function provide a measure of the anticipated federal funds rate $\left(R F_{t}^{*}\right)$. The unanticipated portion of the federal funds rate $\left(\mathrm{RF}^{\mathrm{u}}\right)$ is simply the actual federal funds rate minus the anticipated rate. The models we estimate using the federal funds rate as a measure of monetary policy again are those given by equations $2,3,4$ and 10 , where the unanticipated $\left(\mathrm{g}^{\mathrm{n}}\right)$ or anticipated monetary policy variables $\left(\mathrm{g}^{*}\right)$ are now in terms of the

\footnotetext{
The anticipated federat funds rate is a function of 1 ) consistent forecasts of future values of the unemployment rate, the inflam tion rate and external balance varbabes and 2) lagged values of deviations of actual $M I$ from its target values. See Richard $K$. Abrams, Richarl Froyen and Roger N. Wazd, "Monetary Policy Reaction Fanctions, Consistent Expectations, and the Bums Exa," Ioumal of Money. Credit, and Banking (Febraary 1980), pp. $30-42$.
}

federal funds rate. The results of these tests are given in table 4 .

The results of estimating equations 2,3 and 4 are shown in part $A$ of the table. These results, using the interest rate as a measure of monetary policy, are less favorable to the efficient market hypothesis than our estimates using monetary aggregates. As can be seen from the first two lines of the table, lagged values of the unanticipated portion of the federal funds rate (lagged errors in forecasting the monetary authority's funds rate setting) appear to affect stock retums significantly. This evidence supports the view that stock retums lag monetary policy - even though our results in the previous section would indicate that stock returns do not lag money grow th. The addition of current or future federal funds rate prediction errors does not increase the explanatory power of the equation (see estimates of equation 4 in the table).

In part $B$ of the table, we report estimates of the model that allows both anticipated and unanticipated monetary policy to affect stock prices. Our estimates indicate that lagged values of both unanticipated and anticipated monetary policy as measured by the federal funds rate have significant effects on stock retums. Both here and in part $A$ of the table, all the significant coefficients on the federal funds rate variables are negative (the signs of these coefficients are not reported in the table). This accords with the conventional expectation that a tightening of monetary policy, as measured by an increase in the federal funds rate setting, lowers stock prices and, hence, stock returns. In part B, as in part $A$ of the table, however, the finding that past available information significantly affects stock returns raises questions about market efficiency.

This is not to say that the results in table 4 directly contradict the efficient market hypothesis. One interpretation of these results that is potentially consistent with the efficient market view is that the federal funds rate is a determinant of the expected real return on stocks, which is not a constant. With th is interpretation, the excess return on stocks would still be independent of past avalable information, the condition for an efficient market. Still, the results in table 4 do suggest the possibility that while the market efficiently absorbed data on monetary aggregates, infomation carried by observations on the federal funds rate was not immediately reflected in stock prices and, hence, affected future stock returns. 


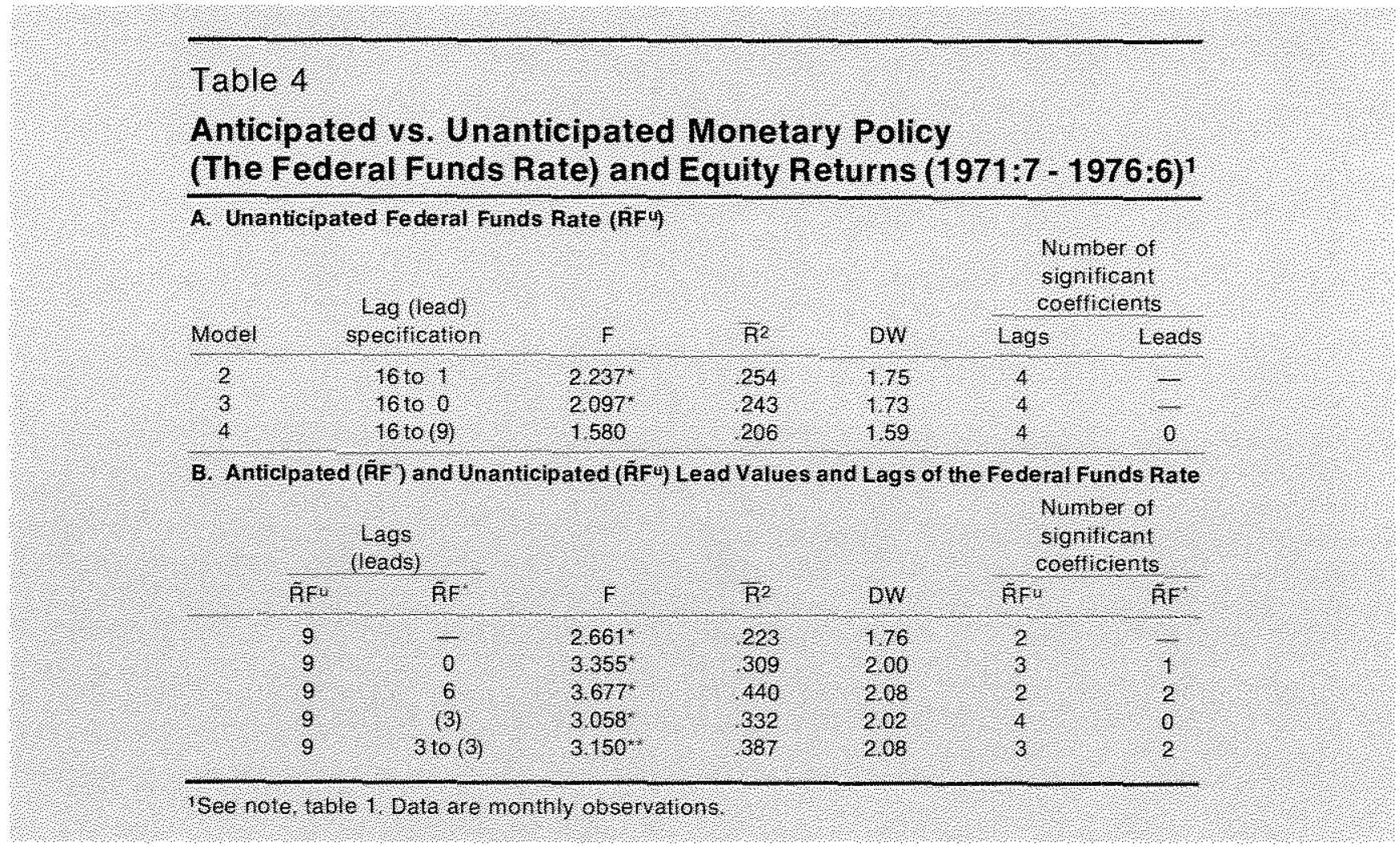

\section{Teses with Weekly Money Stodk Dara}

Earlier tests that split money growth into anticipated and unanticipated components are redone? using weekly data. The meas ures of anticipated and unanticipated weekly money growth are taken from Naylor. ${ }^{20}$ The time period for these tests is August 1974 to March 1977.

As noted, the use of weekly data provides a finer test of possible leadrlag relationships between money growth and stock retums. Data on the money supply generally were announced during our sample period on Thursday aftemoons. Therefore, we assume an injection of monetary information occurs Thursday, which is new infomation to Friday's stock market transactions. By moving to a weekly model, we better capture these events. All money stock data used are the values originally announced on the Thursday of each week. The equity retums are derived from the stock prices recorded at market closing on the next day, Friday.

\footnotetext{
20 Naylor's forecasts are from a 52 -week antoregressive scheme. This model is reestimated one week at a time over the entire sample period and generates one-week-ahead forecusts. For details, see John A. Naylor, "Do Short-Term Interest Rate Expectations Respond to New Information on Monetary Growth?" Southern Economte Joumal January 1982), pp. 754-63.
}

Table 5 presents the summary data from our weekly regression tests. The top of the table (part A) reveals that up to 16 lags and nine leads of unanticipated money growth explain very little of the variance in weekly stock returns. None of the individual coefficients are statistically significant at the 5 percent level of confidence. The $F$-values suggest that none of the three lag specifications leads to a rejection of the null hypothes is of market efficiency.

The bottom half of table 5 (part B) specifies past values of both anticipated $\left(\tilde{g}_{1}^{*}\right)$ and unanticipated monetary growth $\left(\tilde{g}_{1}^{\mathrm{u}}\right)$ as determinants of the weekly equity returns. Adding six past weeks of anticipated monetary grow th improves the explanatory power of the equation (with 16 lags of unanticipated money), doubling the $\overline{\mathrm{R}}^{2}$ to .166 . The main contribution in statistical significance comes from the current value of $\tilde{g}_{1}^{*}$ with less added by the one week lag ( $t$-value equal to about -1.7$)$. The signs of the estimated coefficients are negative, implying an incerse relationship between anticipated money growth and equity retums. ${ }^{21}$

\footnotetext{
21'This finding would agree with the federal funds me results if expectations of inereased monetary growth are at least partially caused by earlier below-target growth. In this case, both higher expected money and higher federal funds rates would correlate with future falling stock returns.
} 
Table 5

Anticipated and Unanticipated Monetary Growth and Equity Returns $(1974: 8-1977: 3)^{1}$

A. Unanticipated Money Growth (g)

\begin{tabular}{|c|c|c|c|c|c|c|}
\hline \multirow[b]{2}{*}{ Model } & \multirow{2}{*}{$\begin{array}{l}\text { Lag (lead) } \\
\text { specilication }\end{array}$} & \multirow[b]{2}{*}{ F } & \multirow[b]{2}{*}{$\sqrt{2}$} & \multirow[b]{2}{*}{ Dw } & \multicolumn{2}{|c|}{$\begin{array}{l}\text { Number or } \\
\text { signifroant } \\
\text { coeffictents }\end{array}$} \\
\hline & & & & & Lags & teads \\
\hline 2 & 1601 & 947 & 084 & 2.02 & 0 & $\rightarrow$ \\
\hline 3 & 16160 & 897 & 085 & 202 & 0 & 0 \\
\hline 4 & $46(0,9)$ & 890 & 115 & 2,03 & 0 & 0 \\
\hline
\end{tabular}

B. Anticipated (g) and Uhanticipated Woney Growth $(g)$

\begin{tabular}{|c|c|c|c|c|c|c|}
\hline 94 & 9. & ff & $R^{2}$ & DW & 9 & 9 \\
\hline $\begin{array}{l}16 \\
16 \\
6\end{array}$ & 8 & $\begin{array}{l}897 \\
1,302\end{array}$ & $\begin{array}{l}085 \\
16 \\
160\end{array}$ & $\begin{array}{l}202 \\
203 \\
204\end{array}$ & 0 & 1 \\
\hline
\end{tabular}

See note, table 1 . Date are weekly observations:

Overall, the results of weekly data indicate that information about money grow th is quickly reflected in stock prices, as one would expect if the market is efficient.

\section{CONCLUSIONS}

The results of our study can be summarized as follows: Estimates of the relationship between stock returns and money growth rates, using monthly data, support the notion that stock markets are efficient. Even from week to week, the market seems to quickly utilize the most recent information on monetary aggregates. Our estimates of the relationship between stock returns and monetary policy actions as measured by the federal funds rate, howm ever, suggest a possible violation of the conditions for market efficiency.

On the question of whether stock retums lead money growth, our results indicate that when anticipated money growth is a fitted value from a reaction function, future unanticipated money growth does not significantly affect current stock returns. But when future changes in money growth rates are based only on past money (using a third-order autoregressive scheme), they do significantly affect returns. This finding supports the hypothesis that the market uses information other than past money growth rates (information embodied in the reaction function prediction) to forecast future money growth and that such anticipations affect current stock returns.

This research has uncovered very little about how one can use monetary policy in formation for profit in the stock market. Information about aggregates is quickly assimilated by markets. The monthly estimations show little effect of anticipated or unanticipated aggregates (base or M1) upon stock returns. The weekly tests suggest that stock returns tend to fall within a week after the market anticipates a rise in the week's monetary aggregate. The most useful information seems to come from the monthly federal funds rate. We found that increases in that rate tended to lower stock returns over a six-to ninemonth period. Since the federal funds rate is an imperfect indicator of monetary policy, this finding may say little about how monetary policy affects stock retums. It does, however, reveal that for our 1971-76 sample period, months when the federal funds rate fell were followed by periods of rising stock refurns. Had market participants been aware of this relationship, they might have profited by it. Since the expressed policy of the Federal Reserve today allows the federal funds rate to float within a wide band, there is no indication that th is relationship continues. The relationship between monetary growth or movements in the federal funds rate and stock returns in the post-October 1979 period is a subject for future research. 